\title{
Germ cell development in female pouch young of the tammar wallaby (Macropus eugenii)
}

\author{
G. T. Alcorn* and E. S. Robinson \\ School of Biological Sciences, Macquarie University, North Ryde, New South Wales 2113, Australia
}

\begin{abstract}
Summary. The cytology, timing, numbers and arrangement of germ cells in gonads of 35 female tammar wallaby pouch young aged from newborn to 210 days post partum were determined from serial sections. Germ cell cytology was essentially similar to that in eutherians. The total number of germ cells per ovary reached a peak of about $4.5 \times$ $10^{5}$ at 50 days and was reduced to about $25 \%$ of the maximum value by 210 days. The first oogonia developed from primordial germ cells soon after birth; the first meiotic oocytes were formed between 24 and 30 days; follicularization of diplotene oocytes began at about 50 days, and by 210 days normal, prefollicular germ cell development had ended. Successive stages of germ cells were initiated at the inner margin of the cortical region of the gonad and spread as a series of waves to the tunica albuginea. At all stages of oogonial and oocyte development many cells showed characteristic degenerative changes leading to atresia. The timing of female germ cell development in relation to gestation in tammars and humans is comparable if tammar gestation is taken to include pouch life.
\end{abstract}

\section{Introduction}

Detailed descriptions of the early pattern of development of female germ cells have been published for several species of eutherian mammals, including the rat (Beaumont \& Mandl, 1962), man (Baker, 1963), guinea-pig (Ioannou, 1964), rhesus monkey (Baker, 1966), pig (Black \& Erickson, 1968), sheep (Mauléon, 1969, 1975), horse (Deanesly, 1975, 1977) and calf (Prépin, Jost \& Vigier, 1977). By contrast, accounts of germ cell development in female marsupials are very restricted. Aspects of oogenesis have been described in the opossum Didelphis virginiana (McCrady, 1938; Morgan, 1943), in bandicoots of the genera Perameles and Isoodon (Ullmann, 1978, 1981), and in a kangaroo Macropus robustus (Robinson, Johnston \& Sharman, 1977), but a comprehensive account of the cytology, timing, numbers and arrangement of germ cells in marsupial females has not previously been published.

In this paper, we give details of the early patterns of female germ cell development in the Australian macropodid marsupial Macropus eugenii. The origin, arrangement and differentiation of somatic cells in the tammar ovary and the interactions of somatic and germ cells will be described in a subsequent paper.

\section{Materials and Methods}

The breeding colony of tammar wallabies was maintained at Macquarie University, Sydney, from an original stock taken on Kangaroo Island, South Australia. Daily pouch inspection of adults

* Present address: The Milperra College of Advanced Education, P.O. Box 108, Milperra, New South Wales 2214, Australia. 
approaching the expected time of birth established the birth date of any newly found young. The day of birth was designated Day 0 and all ages of pouch young are given as days post partum (p.p.). Occasionally the date of birth could not be determined directly and age was estimated from pouch young growth curves (Berger, 1970). In the absence of embryonic diapause, the period from mating to birth occupies about 4 weeks and the young are permanently out of the pouch at about 270 days p.p.

The entire caudal halves of pouch young up to age 24 days were fixed in Bodian's fluid, embedded in paraffin wax and serially sectioned at $10 \mu \mathrm{m}$. The gonads of young more than 24 days old were dissected out since the ossification of the pelvic girdle made sectioning difficult. A consistent schedule of fixation, dehydration and embedding was followed to reduce the problem of differential shrinkage effects. The sections were stained with Harris' haematoxylin and eosin and examined by high-power, bright-field or phase-contrast microscopy. Both gonads of 35 female pouch young aged from newborn to 210 days were examined histologically.

Pouch young before Day 10 were karyotypically sexed by examining mitotic metaphase spreads of liver cells using a colchicine, hypotonic citrate, lacto-aceto-orcein sequence (Ford \& Hamerton, 1956). Pouch young older than 10 days were phenotypically sexed with confidence from the clearly distinguishable scrotal or pouch anlagen.

The mean cell diameter for each germ cell type was calculated from measurements of the long and short axes of about 50 cells of each type and the mean cell volume was calculated by assuming the cells to be spherical. Total germ cell populations in individual ovaries were estimated using the technique of Chalkley (1943) as modified by Beaumont \& Mandl (1962), Baker (1963) and Ioannou (1964).

\section{Results}

\section{Germ cell cytology}

Primordial germ cells within the gonadal ridges (Pl. 1, Fig. 1) were rounded to oval or irregular in outline. Variability in shape did not allow accurate determination of cell size but they were clearly larger than surrounding somatic cells. The cytoplasm was weakly eosinophilic and agranular and the nucleus oval to kidney-shaped with a well-defined envelope. Diffuse chromatin threads extended from the envelope to the prominent eosinophilic central or subcentral nucleolus. Small clumps of heterochromatin were present around the inner margin of the nuclear envelope and smaller granules surrounded the nucleolus. In some nuclei, an enlarged mass of nucleolusassociated heterochromatin was also seen.

Identification of the earliest oogonia was not reliable because of their similarity to primordial germ cells. Daughter oogonia (Pl. 1, Fig. 2) in interphase were larger and in close contact. These groups or 'clones', together with layers of enveloping somatic cells, formed germ cell nests which

\section{PLATE 1}

Germ cells of the tammar wallaby. Scale bar $=5 \mu \mathrm{m}$.

Fig. 1. Primordial germ cell with conspicuous nucleolus and associated heterochromatin.

Fig. 2. Two normal oogonia (below) and an oogonium probably in the early stages of degeneration (above).

Fig. 3. An oogonium in prophase of mitosis (above) and an atretic oogonium (below).

Fig. 4. Oogonia at metaphase with a degenerating 'raspberry' form (below).

Fig. 5. Late leptotene oocytes.

Fig. 6. Zygotene cells, with evidence of bouquet (above).

Fig. 7. Pachytene cells, normal (above) and degenerating (below).

Fig. 8. Normal early diplotene oocyte with surrounding somatic cells and other degenerating diplotene cells.

Fig. 9. Atretic diplotene oocyte.

Fig. 10. Follicular diplotene oocyte.

Fig. 11. Follicular dictyate oocyte. 
PLATE 1
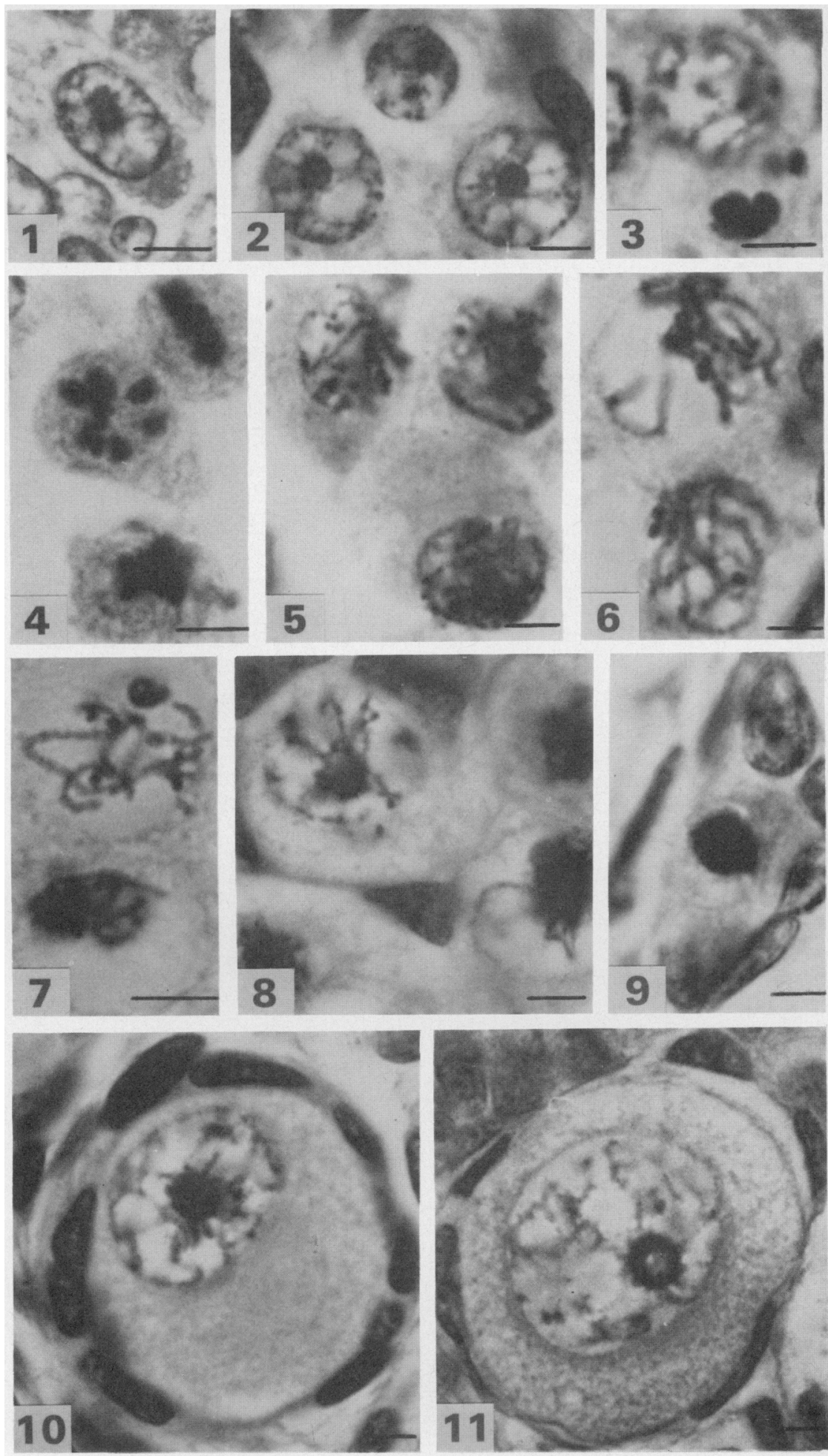

(Facing p. 320) 
correspond to the structures traditionally known as Pflüger's tubes or cords. Oogonial cell membranes were indistinct. Within the rounded nucleus there were chromatin strands containing heterochromatic granules and an enlarged mass of nucleolus-associated chromatin was often present. Mitotic oogonia (P1. 1, Figs 3 \& 4) were distinguished from mitotic somatic cells in histological sections by their location within cell nests and by their larger size. Atretic oogonia contained chromatin fully contracted into a tight central mass (Pl. 1, Fig. 3). Degenerating oogonia were also observed at mitotic metaphase when the chromosomes were clumped in the 'raspberry' configuration (Pl. 1, Fig. 4) referred to by Beaumont \& Mandl (1962).

Oocytes were presumed to form in older cell nests with the transformation of oogonia into a preleptotene condensation stage already described in several eutherians (Hartung \& Stahl, 1977). However, in sectioned tammar material the distinction between early prophase of oogonial mitosis and preleptotene could not be made.

Normal leptotene oocytes were slightly larger than interphase oogonia and the cytoplasm was more granular and eosinophilic. The nucleus was rarely located centrally, the nucleolus stained very weakly with eosin and the fine chromosomal threads appeared as a diffuse network (P1. 1, Fig. 5). All cells within a cell nest were in leptotene at about the same time and this synchrony usually persisted in later oocyte stages. At zygotene (Pl. 1, Fig. 6), the paired chromosomes were less extended and assumed the classical bouquet arrangement whereby their telomeres were attached to a restricted region of the envelope inner surface, leading to looped configurations. At pachytene (Pl. 1, Fig. 7), the bivalents were shorter and thicker and there was some evidence of a banding pattern. Diplotene was the stage of greatest increase in size during oocyte development (Text-fig. 1). Chromosomes were longer and thinner, almost all traces of the bouquet arrangement were lost and the nucleolus was very prominent (P1. 1, Figs $8 \& 10)$.

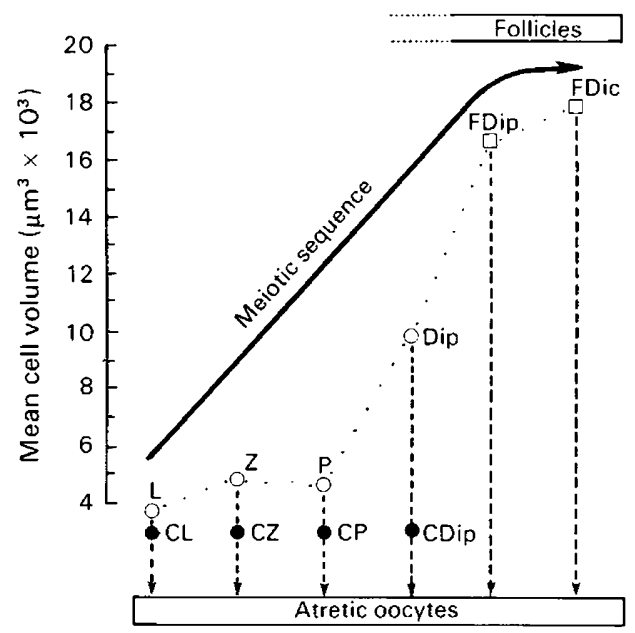

Text-fig. 1. Pattern of development of normal and degenerating oocytes in the tammar wallaby. $\bigcirc$, Normal oocytes; , contracted (degenerating) oocytes; $\square$, follicular oocytes. $\mathrm{L}=$ leptotene $;=$ zygotene $; P=$ pachytene $;$ Dip = diplotene $;$ FDip $=$ follicular diplotene $;$ FDic $=$ follicular dictyate $; \mathrm{C}=$ contracted.

Normal diplotene cells were soon associated with a few flattened somatic cells to form the earliest primordial follicles. An occasional late pachytene cell was observed with surrounding somatic elements but it was typically a diplotene event. Primordial follicle formation eventually led to the breakdown of cell nest organization. Inclusion of more than one diplotene oocyte within a (polyovular) follicle was quite common. The end-point of oocyte development in pouch young was the follicular dictyate stage (Pl. 1, Fig. 11). Differences between diplotene and dictyate oocytes 
were rather subtle. Identification of the two types in sectioned material was possible, although airdried preparations from cell suspensions showed the differences more clearly. Compared with diplotene, dictyate chromosomes were more diffuse; clumps of heterochromatin were widely distributed; the nucleolus was surrounded by more heterochromatic granules and was strongly eosinophilic with a distinct cavity. Some polyovular follicles persisted in the dictyate state.

Degeneration in non-follicular oocytes was heralded by chromosome contraction. The chromosomes were clumped and occupied only part of the volume of the nucleus. Cell size of contracted forms (Text-fig. 1) was slightly reduced in leptotene, zygotene and pachytene but at nonfollicular diplotene the contracted form was smaller than normal and the cytoplasm was more granular and eosinophilic. All these contracted forms finally led to a similar type of fully-contracted atretic cell (P1. 1, Fig. 9) characterized by its small size and a knot of chromosomal material in the centre of the nucleus. Atretic stages were also found in diplotene and dictyate follicular oocytes, but intermediate contracted stages were not seen.

\section{Timing and numbers of germ cells}

The major wave of primordial germ cell migration to the gonadal ridges is known to occur at the beginning of the 4th week of embryonic development (Alcorn, 1975). In the gonadal ridges of newborn wallabies, germ cells were present but they were not identified as primordial germ cells or oogonia. By Day 4 all the germ cells appeared to be larger and at the oogonial stage. Text-figure 2 shows the estimated total number of germ cells (normal and degenerating) per ovary in pouch young aged from 4 to 210 days. The rapid increase in the germ cell population up to 50 days was entirely due to oogonial proliferation. Between Days 24 and 30 the transition of oogonia to oocytes began and the germ cell population became mixed. By Day 30 leptotene and zygotene stages appeared; pachytene cells first appeared between Days 40 and 42, and the earliest diplotene cells were formed between Days 45 and 50 . Diplotene cells rapidly became associated with somatic (follicular) cells since the earliest primordial follicles were found in a 50 -day ovary. The first

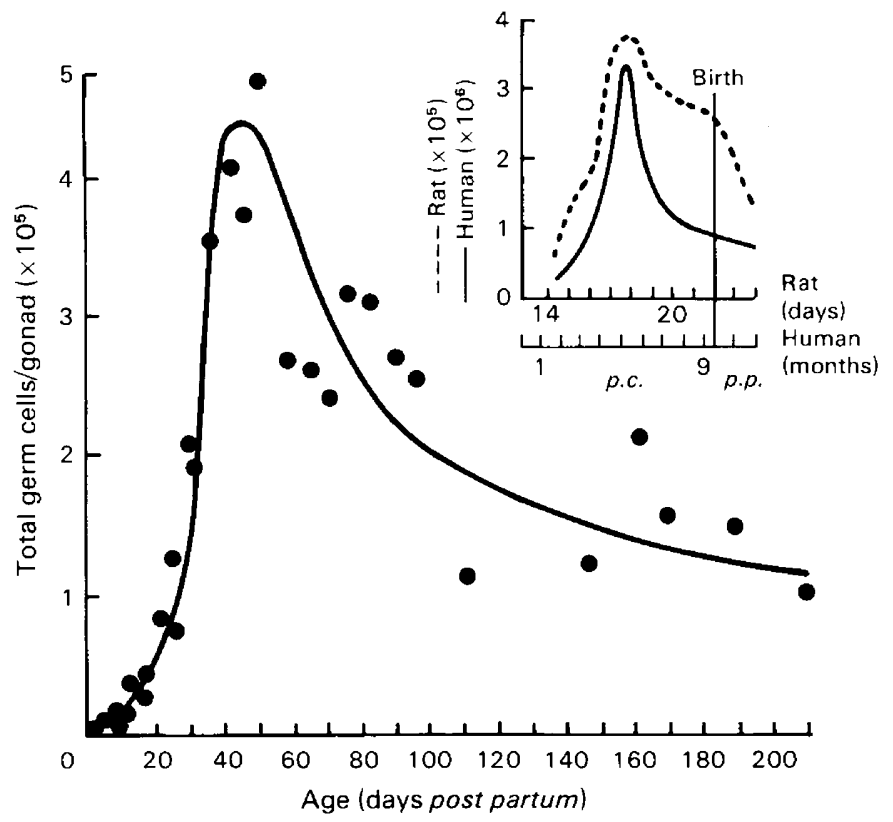

Text-fig. 2. Total germ cell populations in tammar pouch young up to 210 days p.p. Inset: Total germ cells in prenatal and early postnatal stages of rat (data from Beaumont \& Mandl, 1962) and human (data from Baker, 1963). 
dictyate oocytes were found at 60 days. By this time all oocyte stages, both normal and degenerating, could be seen while the number of oogonia had fallen sharply. After 60 days the proportions of degenerating oogonia and prefollicular oocytes increased and by 210 days normal representatives of these stages were no longer found.

\section{Germ cell distribution}

At birth, germ cells were concentrated mainly in the peripheral region of the gonadal ridge but some were scattered elsewhere and their amoeboid shape suggested that they were migrating towards the periphery. Oogonial proliferation proceeded in the peripheral region and subsequent oocyte development occurred in a series of 'waves' extending from the inner margin of this cortical region, finally reaching the outermost layers of the gonad (the tunica albuginea and the coelomic epithelium). The frequency of degenerating cells amongst the first-formed cells in each wave was relatively high. Also, the rate of passage through the various stages in the ovarian cortex was more rapid in the middle region of the ovary than towards the anterior and posterior regions.

The organization of oogonia into germ cell nests started at the inner margin of the cortex and eventually spread to the outermost cortical areas (by about Day 50). As this initial wave proceeded, other phases were initiated. For example, the follicular phase was initiated internally about Day 50 and had spread to the periphery by 210 days.

\section{Discussion}

The developmental cytology of female tammar germ cells is essentially similar to that of eutherians. The appearance of bivalents in the tammar is coarser and less tangled since chromosomes are fewer $(2 \mathrm{n}=16)$ and larger than in eutherians. A paranuclear complex identified in various eutherians and found in a bandicoot (Ullmann, 1978) was not evident in primordial oocytes of the tammar.

Vast numbers of tammar oogonia and oocytes undergo degeneration at all stages of their development. Deanesly $(1975,1977)$ found that, in the horse, the first groups of oocytes degenerate and disappear and that, much later, peripheral oogonia develop into oocytes and eventually normal primordial follicles. Black \& Erickson (1968) and Mauléon (1969) suggested a similar pattern in other eutherians. In the tammar there is no such disruption of germ cell development although some degeneration was noted early in each wave of successive stages. Early phases of oocyte degeneration (contraction) at each of the pre-follicular stages of meiosis $I$ in the tammar are like the descriptions of degenerating oocytes in the pig (Bielenska-Osuchowska, 1973).

The onset of follicle formation occurs typically during diplotene in eutherians and in the tammar. Sometimes, tammar oocytes with surrounding somatic cells possessed features more typical of late pachytene which highlights the difficulty of subdividing a continuous process into discrete stages and of allocation of transitional or intermediate types. Deanesly (1975) overcame this problem by recognizing a 'pre-diplotene' stage and found some primordial follicles with oocyte nuclei at this stage in the horse (Deanesly, 1977). In the tammar the initiation of follicle development can clearly take place from the very beginning of diplotene and possibly before. Follicular isolation is regarded as an essential step in the escape from atresia. In the tammar, some follicular diplotene and dictyate oocytes were found to be in an atretic state but degeneration may have begun before rather than after somatic cell enclosure in some of these cases.

Changes in the total germ cell populations in female rats and women before and after birth (reproduced in the inset to Text-fig. 2) show that the tammar curve is more similar to that of women than rats. On the other hand, the maximum number of germ cells per ovary in the tammar lies much closer to previously recorded values for rats than for humans. In the tammar curve (Text-fig. 2), the scatter of points representing total germ cell number in older pouch young may result from a variety of factors. There is a natural variation in the rate of germ cell development and degeneration 
between older pouch young of similar age as well as differences between gonads of the same pouch young. Also, the quantitative methods used for estimating germ cell numbers are of limited accuracy. As the ovary increases in size and histological complexity, the methods designed originally for tissue with uniform cell distribution can be expected to be less reliable.

Timetables of germ cell development in other macropodid species are unlikely to differ markedly from the tammar pattern. A restricted study of ovaries from pouch young of Macropus robustus aged around 60 days (Robinson et al., 1977), showed, however, that primordial follicle formation was more extensive than in tammars of the same age. Timetable comparisons with eutherians are less straightforward. Predictyate germ cell development and the peak in germ cell populations usually occur during fetal life or soon after birth (as in the cat, dog, rabbit, hamster and ferret). In relation to birth, these events occur much later in tammar development. However, birth in marsupials can be considered as 'premature' and does not provide a useful developmental marker for comparisons with eutherian sexual development. When marsupial development is regarded as the period from conception to pouch exit, to include both intrauterine and extrauterine 'gestation' (Sharman, 1976), the timing of various events in germ cell development in the tammar are more usefully compared with those of eutherians. Viewed in this way, the gestation period of the tammar (excluding embryonic diapause) and man are similar, and the timing of major events in the two species, in weeks post coitum, are as follows (human values in parentheses from Baker \& Franchi, 1967; Jost, 1971): earliest meiosis 8 (13); maximum germ cell population 11 (21); last oogonia entering meiosis 26 (31); first follicles 11 (17). At all stages, the tammar is several weeks in advance of the human female fetus.

We thank Mr Ron Moore for technical assistance; Ms Betty Thorn for help in preparation of figures; Ms Margaret Mercieca and Ms Michelle Minard for typing; and Ms Kimberley McGinnes who read the manuscript. Financial support was provided by the Australian Research Grants Committee and the Macquarie University Research Fund. G.T.A. was in receipt of a Commonwealth Postgraduate Award.

\section{References}

Alcom, G.T. (1975) Development of the ovary and urinogenital ducts in the tammar wallaby Macropus eugenii (Desmarest, 1817). Ph.D thesis, Macquarie University, Sydney.

Baker, T.G. (1963) A quantitative and cytological study of germ cells in human ovaries. Proc. roy. Soc. B 158, $417-433$.

Baker, T.G. (1966) A quantitative and cytological study of oogenesis in the rhesus monkey. J. Anat. 100, 761776.

Baker, T.G. \& Franchi, L.L. (1967) The fine structure of oogonia and oocytes in human ovaries. J. Cell Sci. 2, 213-224.

Beaumont, H.M. \& Mandl, A.M. (1962) A quantitative and cytological study of oogonia and oocytes in the foetal and neonatal rat. Proc. $R$. Soc. B 155, 557-579.

Berger, P.J. (1970) The reproductive biology of the tammar wallaby, Macropus eugenii (Desmarest) (Marsupialia). Ph.D thesis, Tulane University, New Orleans.

Bielenska-Osuchowska, Z. (1973) Oogonia and oocyte degeneration and the nutritive macrophages in the process of the development of the ovary in embryos of the domestic pig (Sus scrofa dom. L.) Z. Anat. Entwickl.-Gesch. 142, 37-52.
Black, J.L. \& Erickson, B.H. (1968) Oogenesis and ovarian development in the prenatal pig. Anat. Rec. 161, 45-56.

Chalkley, H.W. (1943) Method for the quantitative morphologic analysis of tissues. J. natn. Cancer Inst. 4, 47-53.

Deanesly, R. (1975) Germ cell development and the meiotic prophase in the fetal horse ovary. $J$. Reprod. Fert., Suppl. 23, 547-552.

Deanesly, R. (1977) Germ cell proliferations in the fetal horse ovary. Cell Tiss. Res. 185, 361-371.

Ford, C.E. \& Hamerton, J.L. (1956) A colchicine, hypotonic citrate, squash sequence for mammalian chromosomes. Stain Technol. 31, 247-251.

Hartung, M. \& Stahl, A. (1977) Preleptotene chromosome condensation in mouse oogenesis. Cytogenet. Cell Genet. 18, 309-319.

Ioannou, J.M. (1964) Oogenesis in the guinea pig. $J$. Embryol. exp. Morph. 12, 673-691.

Jost, A. (1971) Embryonic sexual differentiation. In Hermaphroditism, Genital Ahnormalities and Related Endocrine Disorders, pp. 16-64. Eds H. W. Jones \& W. W. Scott. Williams and Wilkins Co., Baltimore. 
Mauléon, P. (1969) Oogenesis and folliculogenesis. In Reproduction in Domestic Animals, pp. 187-215. Eds H. H. Cole \& P. T. Cupps. Academic Press, New York.

Mauléon, P. (1975) Importance des differentes périodes oogénétiques dans la gonad femelle d'embryon de brebis: contrôle due changement de comportement mitotique on méiotique. Annls Biol. anim. Biochim. Biophys. 15, 725-738.

McCrady, E. (1938) The embryology of the opossum. Am. anat. Mem 16, 1-233.

Morgan, C.F. (1943) The normal development of the ovary of the opossum from birth to maturity and its relation to sex hormones. J. Morph. 72, 27-85.

Prépin, J., Jost, A. \& Vigier, B. (1977) Les cellules germinales des freemartins. Annls Med. Vet. 121, 537-545.
Robinson, E.S., Johnston, P.G. \& Sharman, G.B. (1977) X chromosome activity in germ cells of female kangaroos. In Reproduction and Evolution, pp. 89.94. Eds J. M. Calaby \& C. H. Tyndale-Biscoe. Australian Acad. Sci., Canberra.

Sharman, G.B. (1976) Evolution of viviparity in mammals. In The Evolution of Reproduction; Reproduction in Mammals, Book 6, pp. 32-70. Eds C. R. Austin \& R. V. Short. Cambridge University Press.

Ulimann, S.L. (1978) Observations on the primordial oocyte of the bandicoot Isoodon macrourus (Peramelidae, Marsupialia). J. Anat. 128, 619-631.

Ullmann, S.L. (1981) Observations on the primordial germ cells of bandicoots (Peramelidae, Marsupialia). J. Anat. 132, 581-595.

Received 30 June 1982 